S. KNAUER*, N. KOCH,C. UTH, R. MEUSINGER, O. AVRUTINA, H. KOLUMAR* (SULFOTOOLS GMBH, DARMSTADT AND TECHNISCHE UNIVERSITÄT DARMSTADT, GERMANY)

Sustainable Peptide Synthesis Enabled by a Transient Protecting Group Angew. Chem. Int. Ed. 2020, 59, 12984-12990.

\section{An N-Protecting Group for Solid-Phase Peptide Synthesis in Aqueous Media}

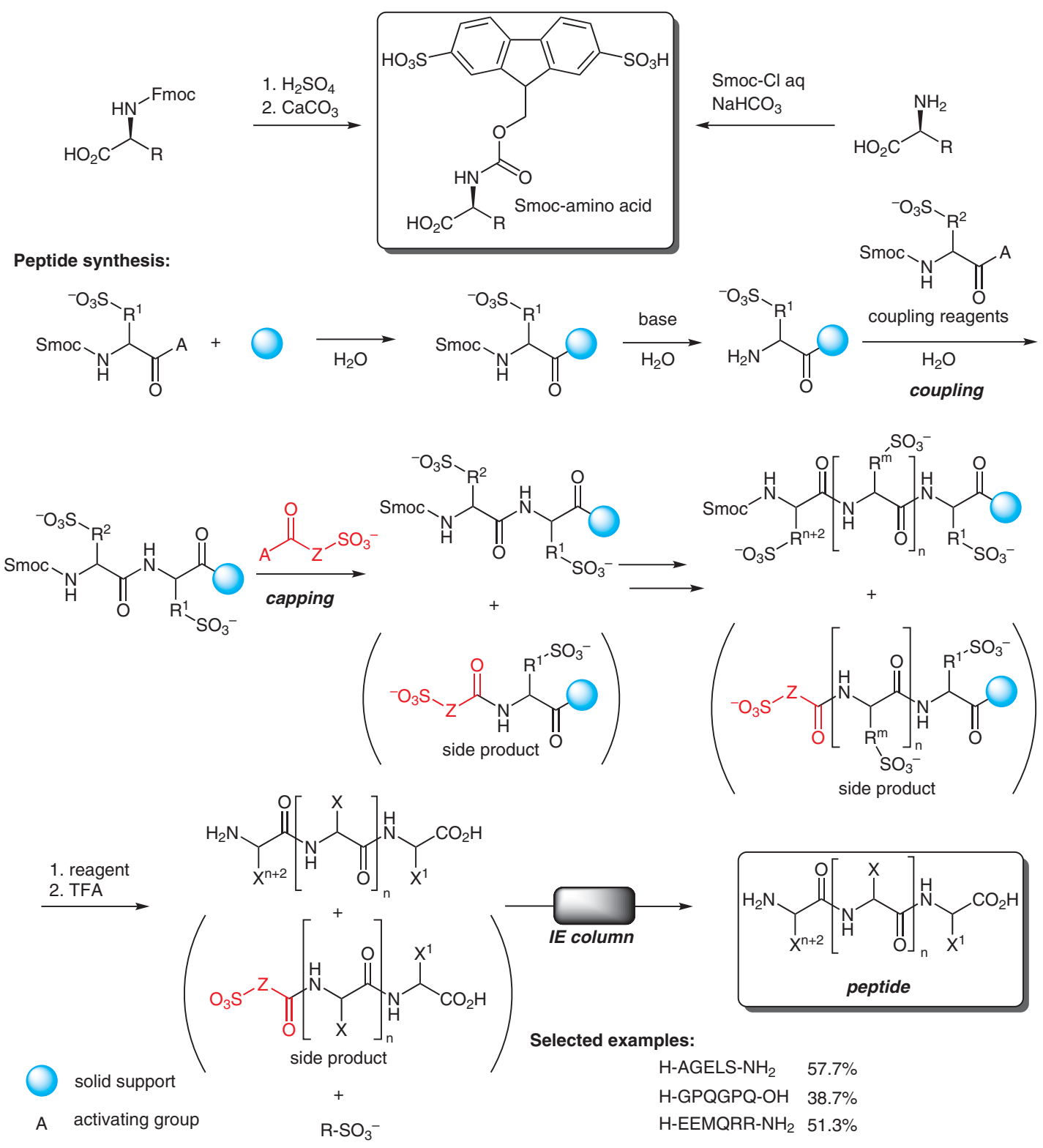

Significance: Peptide synthesis in water as the solvent is underdeveloped. The author have developed a solid-phase peptide synthesis (SPPS) in aqueous media by using a new 2,7-disulfo-9-fluorenylmethoxycarbonyl (Smoc) N-protecting group.

\section{Category}

Peptide Chemistry

\section{Key words}

solid-phase synthesis

peptide synthesis

aqueous media

protecting group

fluorescence
Comment: The authors developed the Smoc group as an N-protecting group. The Smoc group, which is fluorescent, can be used for SPPS in aqueous media and is easily removed. 